\title{
RURAL-URBAN RESIDENCE AND THE PROPENSITY OF EARLY MARRIAGE: A PATH ANALYSIS EVIDENCE FROM LAMPUNG
}

\author{
Nurhayati Agtikasari'), RB. Soemanto²), Bhisma Murti1) \\ 1)Masters Program in Public Heath, Universitas Sebelas Maret \\ ${ }^{2)}$ Faculty of Social and Political Sciences, Universitas Sebelas Maret
}

\begin{abstract}
Background: Globally, approximately 280 girls in 2015 are at risk of early marriage and will increase to 320 in 2050 . This study aimed to determine the effect of internal and external factors on the propensity of early marriage.

Subjects and Method: This was an analytic observational study with a case control design. A sample of 200 married women, consisting of 50 cases of early marriage and 150 controls of timely marriage. The dependent variable was early marriage. The independent variables were education, self efficacy, family income, family support, access of information, parental education, and residence. The data were collected by questionnaire and analyzed by path analysis model.

Results: Early marriage was directly decreased by self-efficacy $(b=-1.89 ; 95 \%$ $\mathrm{CI}=-2.76$ to $-1.01 ; \mathrm{p}<0.001)$, higher family income $(\mathrm{b}=-1.06 ; 95 \% \mathrm{CI}=-1.87$ to $0.26 ; \mathrm{p}=0.009)$, strong family support $(\mathrm{b}=-1.46 ; 95 \% \mathrm{CI}=-2.53$ to $-0.38 ; \mathrm{p}=$ $0.008)$, access of information ( $\mathrm{b}=-1.00 ; 95 \% \mathrm{CI}=-2.02$ to $0.02 ; \mathrm{p}=0.054)$, and urban residence $(b=-1.39 ; 95 \% \mathrm{CI}=-2.22$ to $0.56 ; \mathrm{p}=0.001)$. Early marriage was indirectly decreased by high parental education.

Conclusion: Early marriage is directly decreased by self-efficacy, high family income, strong family support,access to information,and urban residence. Early marriage is indirectly decreased by high parental education.
\end{abstract}

Keyword: early marriage, family income, family support, access of information, residence, girls education, parent education

\section{Correspondence:}

Nurhayati Agtikasari. Masters Program in Public Heath, Universitas Sebelas Maret, Jl. Ir. Sutami 36 A, Surakarta 57126, Central Java.

Email: agtikasari2@gmail.com. Mobile: +6282185965148. 